\title{
HUBUNGAN MINAT BELAJAR SISWA TERHADAP PRESTASI BELAJAR MATEMATIKA SISWA DALAM PEMBELAJARAN KOOPERATIF TIPE STAD MENGGUNAKAN KOMIK
}

\author{
Yustinus Setio Laksono, Gregoria Ariyanti, Fransiskus Gatot Iman Santoso \\ Program Studi Pendidikan Matematika \\ Universitas Katolik Widya Mandala Madiun
}

\begin{abstract}
ABSTRAK
Penelitian ini bertujuan untuk mengetahui pengaruh minat belajar siswa menggunakan komik sebagai media pembelajaran dengan pembelajaran kooperatif tipe STAD terhadap prestasi belajar siswa pada mata pelajaran matematika. Jenis penelitian yang digunakan ialah penelitian kuantitatif yang dikategorikan sebagai hubungan (asosiatif). Populasi dalam penelitian ini adalah siswa-siswi SMPK Santo Yusuf Madiun dan yang menjadi sampel adalah siswa-siswi kelas VII dengan rincian kelas VII A dengan jumlah 27 siswa dan kelas VII B dengan jumlah 38 siswa. Hasil penelitian ini adalah ada pengaruh yang signifikan antara minat belajar siswa dalam hal perasaan senang, perhatian dan kemauan secara bersama-sama terhadap prestasi belajar siswa dengan hubungan positif antara minat belajar siswa dalam hal perasaan senang, perhatian dan kemauan secara bersama-sama dengan prestasi belajar pada mata pelajaran matematika dan regresi berganda tiga prediktor didapatkan bentuk persamaan $\mathrm{y}=6.4112+0.4003 \mathrm{x}_{1}+0.5417 \mathrm{x}_{2}+0.2961 \mathrm{x}_{3}$ dengan $\mathrm{x}_{1}$ untuk minat belajar siswa dalam hal perasaan senang siswa, $\mathrm{x}_{2}$ untuk minat belajar siswa dalam hal perhatian siswa, dan $\mathrm{x}_{3}$ untuk minat belajar siswa dalam hal kemauan siswa bernilai positif yang artinya diprediksikan akan meningkatkan prestasi belajar siswa.
\end{abstract}

Kata kunci: Minat belajar, prestasi belajar, STAD

\section{PENDAHULUAN}

Minat adalah kecenderungan yang tetap untuk memperhatikan dan mengenang beberapa kegiatan. Kegiatan yang diminati seseorang, diperhatikan terus menerus yang disertai dengan rasa senang, perhatian, kemauan, konsentrasi, dan kesadaran siswa terhadap pelajaran matematika. Salah satu faktor yang menyebabkan timbulnya kesulitan dalam belajar adalah karena rendahnya minat terhadap pelajaran matematika. Pengamatan Tatik Hartini (2007:3) dalam "Hubungan Antara Minat Siswa Belajar Matematika dan Kebiasaan Belajar Matematika dengan Prestasi Belajar Matematika", diperoleh fakta yang menunjukan kurangnya minat siswa untuk belajar matematika karena kebiasaan belajar siswa yang salah sehingga membuat pelajaran matematika menjadi membosankan.

Dalam upaya menarik minat belajar siswa dalam proses belajar matematika, guru sebagai pendidik perlu menggunakan sebuah media. Media pembelajaran yang digunakan selama proses belajar adalah yang bersifat nyata atau visual. Media belajar yang bersifat visual dapat membuat siswa belajar dalam keadaan senang, mempunyai perhatian dan kemauan terhadap pelajaran yang diminati. Komik sebagai media pembelajaran merupakan salah satu media yang dipandang efektif untuk membelajarkan dan mengembangkan kreativitas siswa. Hal ini disebabkan karena keunikan fungsinya yaitu sebagai media pendidikan dan sebagai media hiburan. Komik sebagai media visual diasumsikan dapat memberikan pengaruh terhadap perolehan pengetahuan sebagai hasil belajar, karena mampu menarik minat dan perhatian dalam menyampaikan informasi (Maulana, 2004:2).

Sebagai upaya untuk mendukung meningkatkan prestasi belajar dan mengubah paradigma bahwa proses balajar masih 
didominasi oleh guru (Trianto, 2007:1) maka sangat penting bagi para pendidik khususnya guru memahami proses pembelajaran. Model pembelajaran yang melibatkan siswa dalam pembelajaran secara langsung dengan menggunakan pembelajaran kooperatif tipe STAD. Gagasan utama dari STAD adalah untuk memotivasi siswa supaya dapat saling mendukung dan membantu satu sama lain dalam menguasai kemampuan yang diajarkan oleh guru. Dengan adanya komik matematika sebagai media pembelajaran yang dipadukan dengan pembelajaran kooperatif tipe STAD dan disertai tingginya minat belajar matematika, akan memudahkan perhatian dan ketekunan siswa serta dapat meningkatkan prestasi belajar siswa dalam mempelajari matematika. Oleh karena itu dengan memiliki minat belajar yang tinggi maka peserta didik lebih giat dalam belajar matematika.

\section{METODE PENELITIAN}

Penelitian ini dikategorikan sebagai hubungan (asosiatif) karena memaparkan hubungan faktor atau berbagai variabel yang mempengaruhi keadaan tanpa memanipulasi variabel tersebut. Populasi dalam penelitian ini adalah siswa-siswi SMPK Santo Yusuf Madiun sedangkan sampel penelitian adalah siswa-siswi SMP kelas VII dengan teknik pengambilan sampel yang digunakan adalah porpusive sampling. Porpusive sampling adalah teknik pengambilan sampel yang digunakan apabila anggota sampel yang dipilih secara khusus berdasarkan tujuan peneliti. Tujuan yang diambil peneliti adalah membahas materi pada sub pokok bahasan garis dan sudut.

Berdasarkan hipotesis yang menjadi variabel terikat adalah prestasi belajar dan yang menjadi variabel bebas adalah minat belajar siswa. Metode yang dipergunakan dalam pengumpulan data adalah metode angket untuk mengetahui minat belajar siswa dan metode tes untuk mengetahui prestasi belajar siswa terhadap mata pelajaran matematika. Teknik analisis yang digunakan analisis korelasi untuk menyatakan hubungan antar minat belajar siswa dan prestasi belajar siswa dan analisis regresi linear berganda untuk menyatakan keberartian konstanta dan koefisien pada persamaan regresi.

\section{HASIL PENELITIAN}

Dari hasil uji normalitas dengan metode Lilliefors taraf uji 5\% didapatkan hasil minat belajar siswa dalam hal perasaan senang berdistribusi normal, minat belajar siswa dalam hal perhatian berdistribusi normal, minat belajar siswa dalam hal perhatian berdistribusi normal dan prestasi belajar siswa dari tes esai berdistribusi normal maka data selanjutnya akan digunakan teknik statistik parametrik.

Berdasarkan hasil analisis mengenai hubungan antara minat belajar siswa dan prestasi belajar siswa yang linier pada mata pelajaran matematika pada taraf signifikan 5\% diperoleh hasil ada hubungan yang signifikan antara minat belajar terhadap prestasi belajar siswa yang linier.

Berdasarkan hasil analisis mengenai hubungan antara minat belajar dalam hal perasaan senang, perhatian dan kemauan dengan prestasi belajar menggunakan analisis korelasi pada taraf signifikan 5\% diperoleh hasil terdapat hubungan positif antara minat belajar siswa dengan prestasi belajar pada mata pelajaran matematika. Dari uji analisis regresi berganda 3 prediktor diperoleh persamaan $\mathrm{y}=6.4112+0.4003 \mathrm{x}_{1}$ $+0.5417 \mathrm{x}_{2}+0.2961 \mathrm{x}_{3}$.

Berdasarkan hasil analisis mengenai hubungan antara minat belajar siswa dan prestasi belajar siswa yang linier pada mata pelajaran matematika. menggunakan analisis uji $\mathrm{F}$ dari perhitungan dapat dijelaskan bahwa minat belajar yang kuat dalam pembelajaran menggunakan komik akan menumbuhkan usaha yang serius dan tidak mudah putus asa dalam mengerjakan soal matematika. Sehingga siswa yang mempunyai minat belajar terhadap pelajaran matematika salah 
satunya dengan memiliki minat belajar dalam hal rasa senang, perhatian dan kemauan terhadap pelajaran matematika sesuai yang pendapat Afni (2009:36) bahwa unsur-unsur minat belajar dibangun dari rasa senang, perhatian dan kemauan. Peran minat dalam belajar meliputi: 1). menciptakan, menimbulkan konsentrasi atau perhatian dalam belajar, 2).menimbulkan kegembiraan atau perasaan senang dalam belajar, 3).memperkuat ingatan siswa tentang pelajaran yang telah diberikan oleh guru, 4). melahirkan sikap belajar yang positif, dan 5). memperkecil kebosanan siswa dalam belajar.

Berdasarkan hasil analisis mengenai hubungan antara minat belajar dalam hal perasaan senang, perhatian dan kemauan dengan prestasi belajar menggunakan analisis korelasi dari perhitungan dapat dijelaskan bahwa $46.75 \%$ variabel terikat yaitu prestasi belajar siswa dipengaruhi oleh variabel bebas yaitu minat belajar yang berkaitan dengan perasaan senang, perhatian, dan kemauan siswa terhadap pelajaran matematika dalam pembelajaran menggunakan komik sedangkan sisanya $(54.25 \%)$ prestasi belajar siswa dipengaruhi oleh variabel lainnya. Minat merupakan faktor terpenting dalam belajar. Minat yang besar dapat mempengaruhi cara belajar siswa. Bahan pelajaran yang menarik minat siswa, lebih mudah dipelajari dan disimpan. Hal ini dikarenakan minat selalu diikuti dengan perasaan senang, perhatian dan kemauan dari situ diperoleh kepuasan

Dari uji analisis regresi berganda 3 prediktor diperoleh persamaan $\quad \mathrm{y}=$ $6.4112+0.4003 \mathrm{x}_{1}+0.5417 \mathrm{x}_{2}+0.2961 \mathrm{x}_{3}$ dan dalam pembelajaran kooperatif tipe STAD menggunakan komik sebagai media belajar dapat diprediksikan bahwa:

1. Konstanta a bernilai positif yang artinya bahwa konstanta a memberikan korelasi yang nyata antara minat belajar siswa terhadap prestasi belajar siswa. Tanpa adanya minat belajar siswa dalam hal perasaan senang, perhatian dan kemauan siswa, prestasi belajar siswa masih dapat meningkat karena masih ada faktor lainnya yang mempengaruhi prestasi belajar siswa.

2. Koefisien $b_{1}$ bernilai positif yang artinya minat belajar siswa dalam hal perasaan senang memberikan korelasi yang nyata terhadap prestasi belajar. Minat belajar yang berupa rasa senang yang muncul dalam diri siswa membuat siswa tertarik pada pelajaran matematika. Perasaan senang terhadap pembelaaran menggunakan komik akan menimbulkan minat belajar pada pelajaran matematika, siswa merasa tertarik kemudian pada gilirannya timbul keinginan yang dikehendaki agar siswa tersebut menjadi senang terhadap pelajaran matematika.

3. Koefisien $b_{2}$ bernilai positif yang artinya minat belajar siswa dalam hal perhatian memberikan korelasi yang nyata terhadap prestasi belajar. Dari perhatian siswa terhadap pelajaran matematika membawa respon positif selama proses pembelajaran. Respon positif inilah yang mampu menumbuhkan minat belajar siswa terhadap pelajaran matematika.

4. Koefisien $b_{3}$ bernilai positif yang artinya minat belajar siswa dalam hal kemauan memberikan korelasi yang nyata terhadap prestasi belajar. Kemauan belajar siswa yang muncul dalam diri siswa dapat memberikan dorongan yang terarah pada suatu tujuan yang dikehendaki oleh akal pikiran. Dorongan ini akan melahirkan timbulnya suatu perhatian terhadap pelajaran matematika sehingga mampu menumbuhkan minat belajar siswa.

\section{KESIMPULAN}

1. Berdasarkan hasil analisis hubungan antara minat belajar siswa dan prestasi belajar siswa yang linier pada mata pelajaran matematika didapatkan hasil ada hubungan yang signifikan antara 
minat belajar menggunakan komik sebagai media belajar dengan pembelajaran kooperatif tipe STAD terhadap prestasi belajar siswa yang linier.

2. Berdasarkan hasil analisis korelasi antara minat belajar dalam hal perasaan senang, perhatian dan kemauan dengan prestasi belajar didapatkan hasil terdapat hubungan yang positif antara minat belajar siswa dalam hal perasaan senang, perhatian dan kemauan yang diperoleh dengan menggunakan komik sebagai media belajar dengan pembelajaran kooperatif tipe STAD dengan prestasi belajar.

3. Dari uji analisis regresi berganda 3 prediktor diperoleh persamaan : $\mathrm{y}=6.4112+0.4003 \mathrm{x}_{1}+0.5417 \mathrm{x}_{2}+$ $0.2961 \mathrm{x}_{3}$ dan dalampembelajaran kooperatif tipe STAD menggunakan komik sebagai media belajar dapat diprediksikan bahwa:

a. Setiap kenaikan 1 skor pada $\mathrm{x}_{1}$ dengan anggapan $x_{2}$ dan $x_{3}$ bernilai konstan dan diikuti kenaikan konstanta 6.4112 maka y akan bertambah 0.4003 .

b. Setiap kenaikan 1 skor pada $\mathrm{x}_{2}$ dengan anggapan $\mathrm{x}_{1}$ dan $\mathrm{x}_{3}$ bernilai konstan dan diikuti kenaikan konstanta 6.4112 maka y akan bertambah 0.5417 .

c. Setiap kenaikan 1 skor pada $\mathrm{x}_{3}$ dengan anggapan $\mathrm{x}_{1}$ dan $\mathrm{x}_{2}$ bernilai konstan dan diikuti kenaikan konstanta 6.4112 maka y akan bertambah 0.2961 .

\section{SARAN}

1. Bagi siswa

a. Bagi siswa yang belum paham dalam menyelesaikan soal matematika dengan menggunakan komik hendaknya tidak malu untuk bertanya kepada teman atau guru. b. Siswa hendaknya mempunyai minat baca yang besar karena isi dan gaya penyampaian pesan mampu merangsang siswa memproses apa yang dipelajari serta memberikan rangsangan belajar.

2. Bagi guru

a. Proses pembelajaran menggunakan media belajar komik perlu mengalokasi waktu secara baik.

b. Dalam memilih komik sebagai media pembelajaran, perlu diupayakan memilih komik yang sudah dikenal oleh siswa.

3. Bagi sekolah

a. Komik bisa menjadi alternatif media pembelajaran dalam proses pembelajaran matematika, karena dapat menarik minat belajar matematika siswa.

b. Diharapkan pihak sekolah menyediakan komik sebagai media belajar, khususnya yang berhubungan dengan pelajaran yang dianggap oleh siswa sebagai pelajaran yang sulit.

\section{DAFTAR PUSTAKA}

Budiyono. 2004. Statistika untuk Penelitian. Surakarta: Sebelas Maret Universitas Press.

Hartini, Tatik. 2007. Hubungan Antara Minat Siswa dalam Belajar Matematika dan Kebiasaan Belajar Matematika Dengan Prestasi Belajar Matematika Siswa Kelas VII SMUK St Bonaventura Madiun. Universitas Katolik Widya Mandala Madiun. Skripsi: Tidak dipublikasikan

Idrus, M. 2009. Metode Penelitian Ilmu Sosial. Jakarta:Erlangga

Maulana. 2008. MATEMATIKOMIK sebagai Alternatif Media dalam Pembelajaran Matematika untuk 
Meningkatkan Motivasi dan Prestasi Belajar Siswa Pada SMA Negeri 3 Bandung dalam http://hidup-penuhperjuangan.blogspot.com/2008/1 1matematikomik-sebagaialternatif-media.html diakses tanggal 1 Desamber 2011.

Munadi, Yudhi, 2008. Media Pembelajaran, Sebuah Pendekatan Baru. Jakarta: Gaung Persada Press.

Sardiman. 2003. Interaksi dan Motivasi Belajar Mengajar. Jakarta: CV. Rajawali.

Slameto, 2003. Belajar dan Faktor-Faktor yang Mempengaruhi. Jakarta: Rineka Cipta.

Slavin, R. E. 2009. Cooperative Learning Teori, Riset dan Praktek. Bandung: Nusa Media.
Sudjana. 1996. Metoda Statistika. Bandung: Tarsito.

Suyanto, Kasihan K. E. 2007. Model Pembelajaran. Malang: Universitas Negeri Malang.

Trianto, 2007. Model-Model Pembelajaran Inovatif dalam Teori dan Praktek. Jakarta: Prestasi Pustaka. Wahyu

Jayanti, Afni. 2010. Pengaruh Kualitas Komunikasi dalam Keluarga dan Minat Belajar Terhadap Motivasi Berprestasi Siswa SMAK St Bonaventura Madiun Tahun Ajaran 2009/2010. Universitas Katolik Widya Mandala Madiun. Skripsi: Tidak dipublikasikan. 